\title{
An antidote to anarchy? Images of monarchy in Greece in the nineteenth and the twentieth centuries
}

\author{
Spyridon G. Ploumidis \\ National and Kapodistrian University of Athens \\ sploumid@arch.uoa.gr
}

Since Roman times the representation of monarchy as an antidote to anarchy was a strong form of legitimization for the monarchical institution. In modern Greece, this formula dates back to 1821. The Greek Revolution and its republican constitutions were identified by European statesmen with anarchy and demagogy. Thus, a foreign monarch, alien to Greece's internal factions, was deemed the ideal remedy for internecine strife, and the best guarantor of internal unity as well as stability in the Near East. This image of monarchy proved its usefulness again during the First World War, when a controversy between the premier Eleftherios Venizelos and King Constantine over foreign policy and constitutional issues led to the National Schism (1915-17).

Keywords: monarchy; anarchy; Eleftherios Venizelos; National Schism; modern Greece

\section{Introduction}

The era of modernity created new ordeals for monarchy. In the late sixteenth century, a large part of the political literature of the Reformation, such as the anonymous Vindiciae contra tyrannos (Basel 1579), put forward new challenges in regard to the legitimacy of Europe's kings. ${ }^{1}$ In pre-modern polities the ideals of hierarchy, order and divinely appointed sovereignty were the sole and ubiquitous foundations of royal power. ${ }^{2}$ For this reason, the entry into modernity required the search for new forms of legitimacy of monarchy. Legitimation by tradition (e.g. noble birth, or Divine Right) was no longer sufficient, and new forms of popular legitimation, of what the political scientist Samuel E. Finer calls the Palace/Forum type, proved necessary. ${ }^{3}$

1 W. M. Spellman, Monarchies 1000-2000 (London 2001) 18, 194.

2 J. Duindam, Dynasty. A very short introduction (Oxford 2019) 28.

3 The Palace/Forum type of government is a form of constrained autocracy legitimated by some form of popular election and a (genuine or feigned) show of popular support for the autocrat; see S. E. Finer, The

(C) The Author(s), 2021. Published by Cambridge University Press on behalf of the Centre for Byzantine, Ottoman and Modern Greek Studies, University of Birmingham. This is an Open Access article, distributed under the terms of the Creative Commons Attribution licence (https:/creativecommons.org/licenses/by/4.0/), which permits unrestricted re-use, distribution, and reproduction in any medium, provided the original work is properly cited.

DOI: $10.1017 /$ byz.2021.6 
In practice this meant that in modernity, kings had to seek some form of popular election sympathies, so as to avert allegations that they were, or ruled as - in Aristotelian terms - 'tyrants' (tyrannoi). ${ }^{4}$ In the century and more that followed the turmoil of the French Revolution (1815-1914), the spread of nationalism and liberalism at the expense of dynasticism produced an environment even more inimical to monarchs: after the fall of Napoleon it was clear that, if monarchy were to survive in a modern European setting, royal families had to position themselves not as God's agents on earth, but instead as servants of the nation and an antidote to lawlessness and civil strife. ${ }^{5}$

My aim in this article is to explore images of monarchy in Greece in the nineteenth and the twentieth centuries, placing particular emphasis on the multifaceted notion of anarchy, which appears to have been the most useful (though not the sole) spectre used by royalists during the period for the legitimization of monarchy and the restoration of monarchs. In doing this, I seek to make a contribution to the understanding of the function and the structural role of the monarchical form of government in the Greek state within its European and South-east European setting. For, as Jeroen Duindam rightly notes, while the histories of individual kings and queens are well known, the collective history of kingship and dynasty remains a terra incognita. ${ }^{6}$

\section{Monarchy versus 'anarchy'}

In modern Greece, this formula of legitimizing monarchy dates back to the Revolution of 1821. As the secretary of the first British Legation to independent Greece explains, the Greek Revolution (as a war crisis in the Near East) and its republican constitutions were identified by European statesmen and diplomats, in the reactionary spirit of Restoration, as 'anarchy' and 'demagogy' and condemned by the Allied Great Powers at the Verona Conference in 1822 as a 'danger to peace and social order' in Europe.'

For this reason, in as much as anarchy was considered a political hazard on both the international and the domestic level, monarchy served a dual purpose. In particular, as the diplomatic historian Michel Lhéritier noted in 1925, monarchy was initially imposed on Greece as a cure for 'anarchy' and 'immorality' (a reference to the Revolution of 1821), and as a bearer of 'harmony' and 'political stability' to the newly

History of Government from the Earliest Times, 1 (Oxford 1997) 1.39-40; 3.1474. Divine Right is a doctrine of royal legitimacy that stems from the claim that kingship descended from Heaven, and that therefore the king is the agent of God, or at least derives his authority from Divine Providence; see B. Crick, 'Monarchy', in W. Outhwaite (ed.), The Blackwell Dictionary of Modern Social Thought, 2nd edn (Malden, MA 2003) 407.

4 Finer, The History of Government, 1.40-57; 3.1554.

5 Spellman, Monarchies, 209-10.

6 Duindam, Dynasty, 2.

7 H. H. Parish, The Diplomatic History of the Monarchy of Greece from the Year 1830 (London 1838) 55, 66, 80, 145 . 
liberated country, as well as a guardian (in the best interests of Europe, which had been shaken by the French Revolution and the Napoleonic Wars) of 'order' and 'tranquillity' in the Near East. ${ }^{8}$ In public imagery, monarchy was counterposed to 'anarchy', because 'only kingship' was in a position to tame 'the rowdy character of Modern Greeks' and to put an end to their 'petty ambitions'.'

To this end, the Greek throne was offered in 1830 to Prince Leopold of Saxe-Coburg, and two years later, upon Leopold's abdication, to Prince Otto of Bavaria. ${ }^{10}$ According to George Finlay, the Scottish Philhellene and contemporary observer, absolute monarchy was deemed by the Three Powers that liberated Greece (Britain, France and Russia) as imperative for the welfare and good government of the new state, particularly after the period of chaos, anarchy and civil war that followed the assassination in 1831 of John Capodistrias, Greece's first governor. ${ }^{11}$ Thus, as John A. Petropulos explains, a foreign monarch, alien to Greece's internal factions, was naturally seen as the best remedy for Greece's internecine strife, the guarantor of her internal unity and stability, and her saviour from self-destruction. ${ }^{12}$ It seems that a decisive role in the final choice of this form of government had been played earlier by Capodistrias himself, who, according to the testimony of the first Austrian envoy to Greece, had maintained that a federal and constitutional polity akin to that of the United States of America, which had initially inspired many Greek revolutionaries, would merely bring 'anarchy'. By contrast, in Capodistrias' mind, monarchy was the sole polity that could 'withstand revolution' and integrate Greece into the contemporary security system of Vienna, which had been established by the victors over Napoleon in 1815, and to the international society of the Restoration known as the Holy Alliance. ${ }^{13}$ As expected, upon his arrival in Greece in 1833, King Otto

8 É. Driault and M. Lhéritier, Histoire diplomatique de la Grèce de 1821 à nos jours, (Paris 1925) 2.5-7.

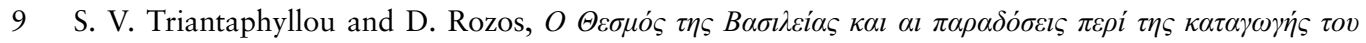

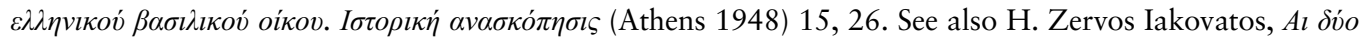

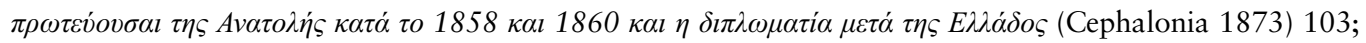
G. Finlay, A History of Greece from its Conquest by the Romans to the Present Time B.C. 146 to A.D. 1864, 7 (The Greek Revolution. Part II. Establishment of the Greek Kingdom), 2nd edn (Oxford 1877)

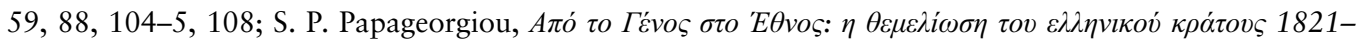
1862 (Athens 2015) 296-7.

10 Parish, The Diplomatic History of the Monarchy of Greece, 136.

11 Finlay, A History of Greece, 7.59, 88, 104-5, 108; J. Mavrogordato, Modern Greece, A Chronicle and a

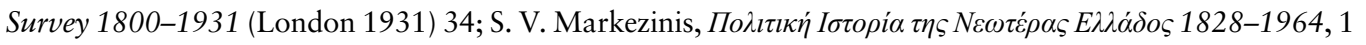

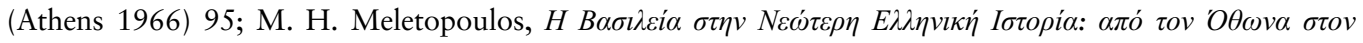

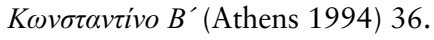

12 J. A. Petropulos, Politics and Statecraft in the Kingdom of Greece 1833-1843 (Princeton 1968) 51.

13 A. Freiherr-von Prokesch-Osten, Geschichte des Abfalls der Griechen vom Türkischen Reich im Jahre 1821 und der Gründung des hellenischen Köningreiches aus diplomatischen Standpunkte, 2 (Vienna 1867)

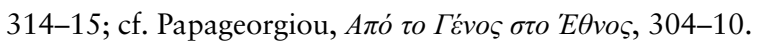


announced that his first duty was to put an end to anarchy and discord, and to restore public order, concord and security. ${ }^{14}$

In the course of time, the formula, monarchy versus anarchy, became more compelling. Thirty years after King Otto's accession, in 1863, the change of dynasty followed the same pattern. As in 1831-2, when anarchy followed the violent death of Capodistrias, the dethronement of Otto caused a serious breakdown of public order, with gangs of bandits reaching the outskirts of Athens, leading to a period of political instability that lasted about a year. ${ }^{15}$ Thus the interregnum of $1862-3$ became, in common perceptions, synonymous with chaos and anarchy. ${ }^{16}$ The biographer of the new king, Georgios Aspreas, wrote that by October 1863, when Prince George of Denmark arrived in Greece, the country had undergone a painful phase of 'absolute anarchy' owing to 'the most awful political discords' which had torn the country apart. ${ }^{17}$ Supporters of the monarchical institution played this card for all it was worth. They stressed that once again and within a relatively short period of time, Greeks had proven themselves unfit for self-rule and republican government. Consequently, George I came to Greece as a Messiah, with the task of restoring order, and tranquillity. ${ }^{18}$ Contemporary historical accounts mention that the public, and particularly conservative politicians, saw in the advent of the King the elimination of the 'anarchy' which had overwhelmed Greece and its capital. ${ }^{19}$ Half a century later, the loyalist axiom that 'the constitutional monarch is the great arbitrator and peacemaker for democratic peoples', especially 'in times of political tension or demagogy', still held sway in domestic politics. ${ }^{20}$ For, according to the perceptions of the time, 'chaos and anarchy meant death for the nations.' 21

The same discourse of legitimizing monarchy in the eyes of Greeks recurred in 1909-10, when the country was once again shaken by political tumult and a mass movement of public protest against the 'oligarchy' (i.e. the political establishment) and

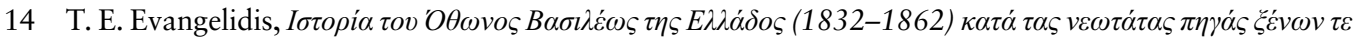

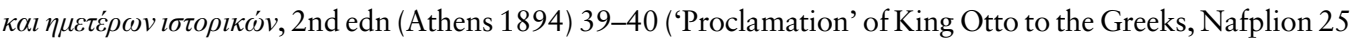
January 1833 , o.s.).

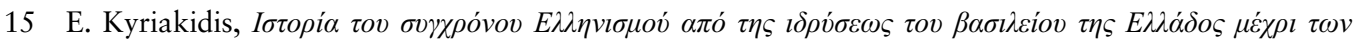

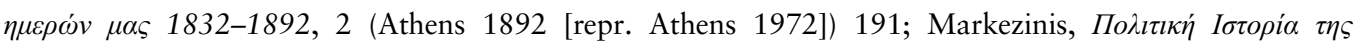

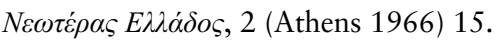

16 Meletopoulos, 42.

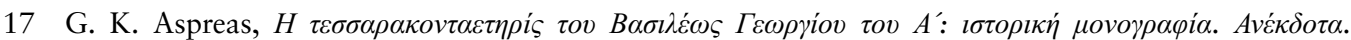

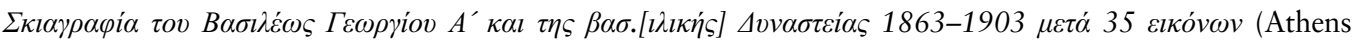
1904) $30,50$.

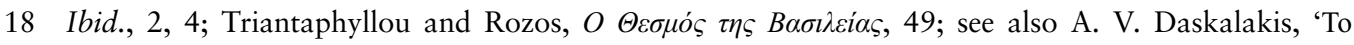

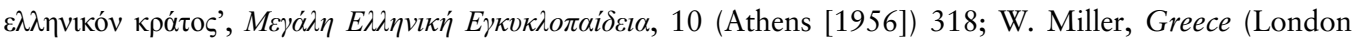
1928) 37.

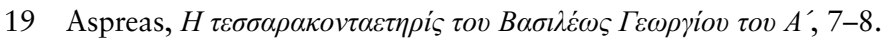

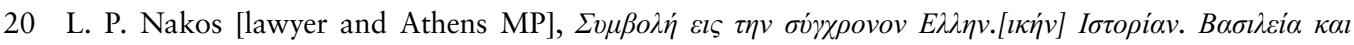

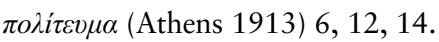

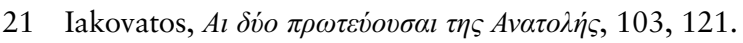


clientelism (synallagi). These led to a military coup (the Goudi 'revolution', as it was called by the putschists), through which the Cretan-born liberal politician Eleftherios Venizelos was elevated to power and hailed by the press as 'the long-expected Messiah' and 'the saviour of the Nation'. With reference to the 1909 'revolution', loyal supporters of monarchy, such as the university professor Neoklis Kazazis, claimed that this popular movement was tantamount to anarchy and social and political 'disintegration'. ${ }^{22}$ For his part, Venizelos went out of his way to counteract this orchestrated attempt by the monarchists to denigrate this 'revolutionary movement', by presenting it as 'anti-dynastic' and inimical to the Crown. ${ }^{23}$ In August 1909, in his first addresses to the putschists, the Cretan statesman asserted that the 'revolution' was not by any means anti-dynastic; its sole enemy, he insisted, was 'the ruling plutocratic oligarchy', not the ruling dynasty, let alone monarchy as such. Therefore, it had no intention of causing anarchy or endangering order in any way. ${ }^{24}$

All in all, at the turn of the twentieth century the institution of the monarchy was presented as an antidote to 'anarchy': social unrest, political instability and civil conflict. ${ }^{25}$ Greece was not an exceptional instance in this modern legitimizing process: compare Romania, where Carol I of Hohenzollern-Sigmaringen replaced Prince Ion Cuza as head of state in 1866. The enthronement of a foreign ruler in Bucharest in the place of an indigenous prince was regarded as a prerequisite for the restoration of political stability in the country. ${ }^{26}$ Along the same lines, in Bulgaria the election of Ferdinand I of Saxe-Coburg-Gotha by the Sobranie (the Bulgarian parliament) in 1887 was aimed expressly at ending an interregnum of 'anarchy', by which was meant the lawlessness, and political instability that followed the dethronement of Prince Alexander I of Battenberg. ${ }^{27}$

As in the early nineteenth century, the word 'anarchy' also had international connotations. Its broadest meaning encompassed the destabilizing potential of the

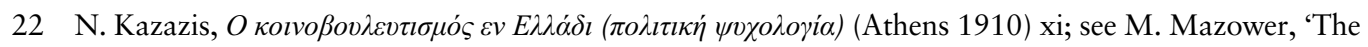
Messiah and the Bourgeoisie: Venizelos and politics in Greece, 1909-1912', The Historical Journal 35.4 (1992) 885-904 (896); H. Gardikas-Katsiadakis, 'Venizelos' advent in Greek politics, 1909-12', in P.M. Kitromilides (ed.), Eleftherios Venizelos: The Trials of Statesmanship (Edinburgh 2006) 97. In terms of British politics, the liberal radicals are identified as 'left liberals'; see K. Passmore, 'Politics', in J. Jackson (ed.), Europe 1900-1945 (Oxford 2002) 86-8.

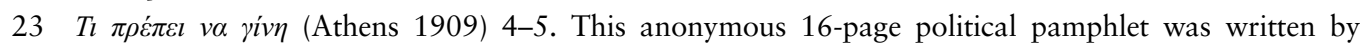
Alexandros Papanastasiou, a future prime minister and associate of Venizelos. At the time, Papanastasiou was primus inter pares within the so-called Sociological Society, a Piraeus-based society of Fabian socialist and radical intellectuals; see A. Papanastasiou, $M \varepsilon \lambda \dot{\varepsilon} \tau \varepsilon \varsigma, \lambda \dot{o} \gamma o l, \alpha \dot{\alpha} \rho \theta \rho \alpha$, ed. X. Lefkoparidis, 1 (Athens [1957]) 45-52.

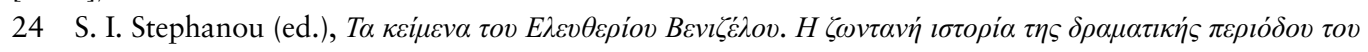

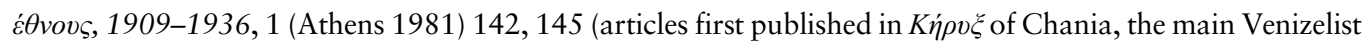
mouthpiece).

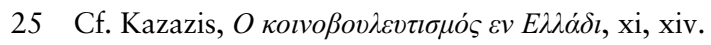

26 L. Boia, Romania: Borderland of Europe, tr. J.C. Brown (London 2006) 87.

27 R. J. Crampton, Bulgaria (Oxford 2008) 131-2. 
diverse national questions that simmered in the Balkans, which signified that it was capable of setting South-East Europe ablaze. However, in the area of foreign affairs additional factors came into play. In the Balkans, foreign dynasties tended to become integral parts of international rivalries; in this context, the fact that most of the dynasties of South-Eastern Europe were of German descent tended to alleviate fears of excessive Russian influence in the region. Indeed, before Bismarck's turn towards a more Anglophobic foreign policy in the mid-1880s, the Germans were viewed by the British as cousins and, in Queen Victoria's own words, as 'a most useful ally' of Britain against Russia. ${ }^{28}$ In Romania in particular, Europe's Great Powers assigned to Carol I the task of curtailing Romanian nationalism and safeguarding peace in the East, especially with the neighbouring Austro-Hungarian empire. To this end, in 1883 Romania joined the Triple Alliance, the defensive pact between Germany, Austria and Italy that revived the Holy Alliance's conservative spirit of monarchical solidarity and aimed at retaining the status quo, stability, and social order in Central and Eastern Europe against the threat of pan-Slavism. At that time, this threat was considered to be an ominous, anarchic revolutionary force, as perilous to the dynastic thrones of Europe as French republicanism. ${ }^{29}$ In a similar manner, George I of Greece was advised, in George Finlay's words, 'to refrain from all aggressive acts against Turkey'; prior to the Greek-Ottoman war of 1897, which was calamitous for Greece, King George had followed a prudent foreign policy, effectively avoiding any drastic military action that would encroach upon the territorial integrity of the Ottoman Empire. ${ }^{30}$

\section{The background and the varied faces of anarchy}

The image of the monarchy as a panacea for anarchy and civil strife was grounded in the Roman legal tradition and political thought. The antithesis dates back to the decades following Republican Rome in the first century BC, when Augustus bestowed upon himself the extraordinary powers of princeps and imperator in order to face the internal crisis of government most efficiently. ${ }^{31}$ In other words, the aversion of modern

28 P. M. Kennedy, The Rise of Anglo-German Antagonism 1860-1914 (London 1980) 7, 125, 167, 178, 182; J. Hawes, The Shortest History of Germany (Exeter 2018) 97-8, 120-3.

29 E. Siupiur, 'Charles $1^{\text {er }}$. Un modèle politique pour les monarques du Sud-Est européen', in E. Binder-Iijima, H.-D. Löwe and G. Volkmer (eds.), Die Hohenzollern in Rumänien 1866-1947: Eine monarchische Herrschaftsordnung im Europäischen Kontext (Cologne 2010) 124, 128-9; cf. P. W. Schroeder, 'International politics, peace, and war, 1815-1914', in T. C. W. Blanning (ed.), The Nineteenth Century Europe 1789-1914 (Oxford 2003) 183-6.

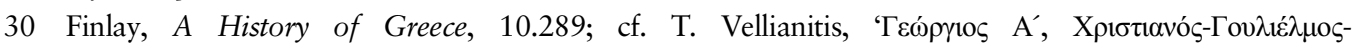

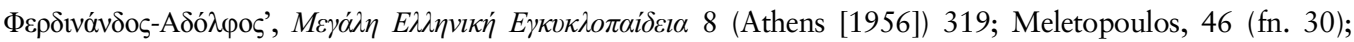

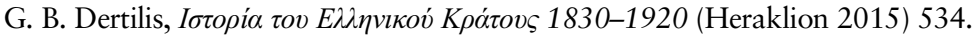

31 C. J. Friedrich, 'Monarchy', in D. L. Sills (ed.), International Encyclopedia of the Social Sciences, X (New York 1968) 412-13; P.-M. Martin, 'Les quatre sources de l'idée monarchique sous la république romaine', in L'idéologie du pouvoir monarchique dans l'antiquité (Paris 1991) 51; Finer, The History of Government, 1.40; Spellman, Monarchies, 17. 
polities to anarchy and their recourse to monarchy was deeply rooted in historical experience: that of internecine strife in the late Roman republic.

At the same time, the ancient Greek (and in particular Aristotelian) aversion to the tyrannos continued to possess a certain resonance. Hence the anxiety of medieval (and later) kings to avert any allegations against them of ruling like tyrants, something that they considered to be highly damaging to their public image. ${ }^{32}$ In modern Greece, particularly after the dethronement of King Otto in 1862, kings systematically sought to avoid any hint or association of their name with tyranny. Accordingly, they represented themselves as 'Princes of a Democratic People', and their throne as being 'established on the love of their People'. ${ }^{33}$ The motto of the Greek monarchs 'My power is the people's love', which King George I, the founder of the second Greek dynasty, borrowed from his Danish dynasty, followed the same populist principle; in fact, this maxim was another ingenious formula against revolution: it was first used by the Danish king Frederick VII in the wake of the upheaval of $1848 .^{34}$

On the other hand, the term 'tyranny' continued well into the twentieth century to be used as a synonym for royal 'despotism' and 'absolutism'. ${ }^{35}$ The identification of monarchy with tyranny was a recurrent theme in the discourse of staunch republicans like Georgios Philaretos, the jurist and former Minister of Justice. ${ }^{36}$ At the turn of the twentieth century, republicans continued to be in the minority in Greece. Yet their cause gained momentum during the First World War thanks to an unprecedented political crisis - in fact, a low-key civil war - that later came to be known as the National Schism. In 1916-17, this crisis, sparked a year earlier by a strong disagreement and open confrontation between Venizelos and King Constantine over foreign policies and constitutional issues, divided Greece into two opposing separate states centred upon Athens and Thessaloniki. ${ }^{37}$ During this period, the Thessaloniki government declared that King Constantine had forfeited his right to the throne and

32 J.-C. Mühlethaler, 'Le tyran à table: Intertextualité et référance dans l'invective politique à l'époque de Charles VI', in J. Blanchard (ed.), Représentations, pouvoir et royauté à la fin du Moyen Âge (Paris 1995) 49.

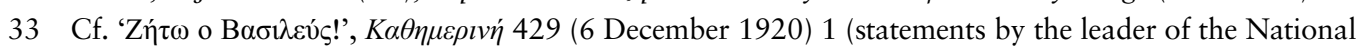

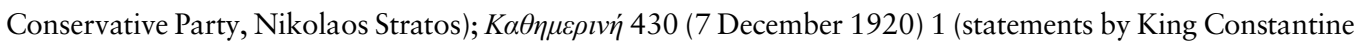
I upon his restoration).

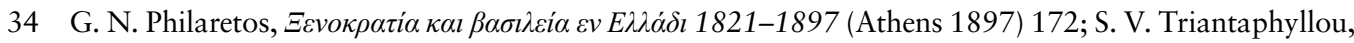

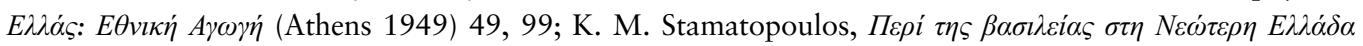

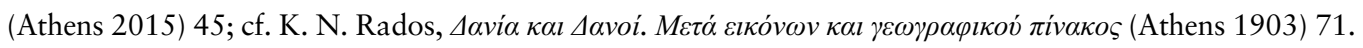

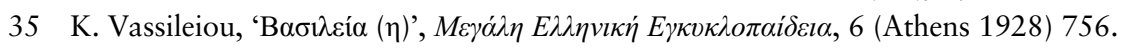

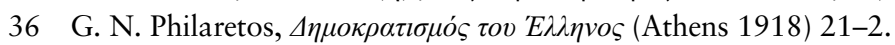

37 The term 'National Schism' was coined as late as 1935 by the journalist and historiographer Ioannis

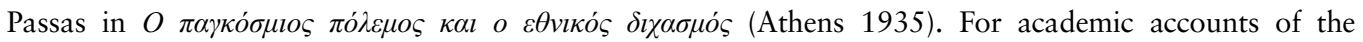

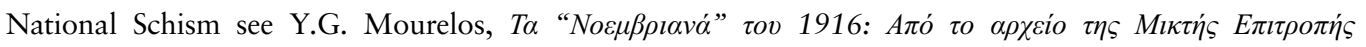

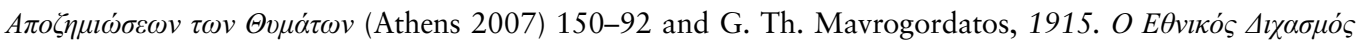
(Athens 2015) 40-121. 
denounced him as a tyrant. ${ }^{38}$ Venizelos and his associates continued to censure Constantine in this most offensive way, with overt references to 'despotism' and 'royal tyranny', over the course of the following four years (1917-20), until Venizelos' fall from power as a result of his crushing electoral defeat on 1/14 November 1920. ${ }^{39}$

Subsequently, monarchy needed to offset such accusations of tyranny, which were painful and might even prove fatal. Its new quest for legitimization involved an opening to popular currents, including strong infusions of populism and paternalism. In 1960, Panagiotis Pipinelis, an eminent advocate of royalism and a future foreign secretary and prime minister, highlighted the fact that the monarch was traditionally seen as 'the true father of the nation' and enjoyed a direct emotional connection with his subjects. ${ }^{40}$ The pinnacle of such populist royalist politics had been the Reservists' movement of 1916, in the midst of the National Schism. The Reservists (Epistratoi), a truly mass movement of over 200,000, openly vowed fanatical devotion and blind allegiance to the Crown; in November 1916, their fanatical royalism issued in a violent pogrom against Venizelists. ${ }^{41}$

Yet, for all the Reservists' forcefulness and fanaticism, it is important to assess the impact of this exercise in paternalism and populism. Elements of monarchist discourse seem to have played a role on a tactical level, cementing the cohesion of the royalist camp, but do not appear to have been particularly useful as tools for popular mobilization. Historically, scaremongering and the spectre of anarchy in the form of civil unrest and strife proved more effective political weapons. The antithesis of monarchy and anarchy appears to have cut across class and partisan politics and to

38 The official denunciation of King Constantine took place on 24 November 1916 (O.S.); see

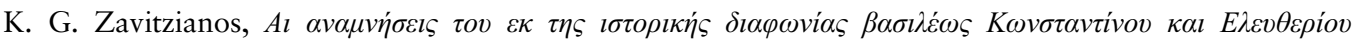

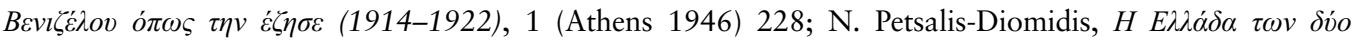

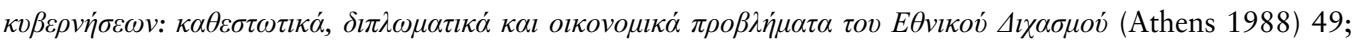
Mavrogordatos, 1915, 100-1.

39 Eөvikń A $\mu v v \alpha 6$ (Heraklion 20 April 1917) 1 ('Manifesto' of Ioannis D. Tsirimokos to 'the Cretan

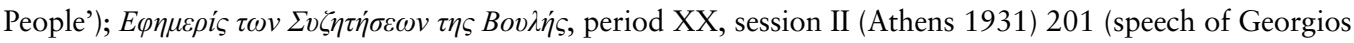

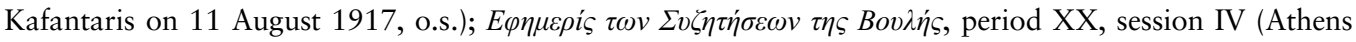
1931) 1059 (speech of Eleftherios Venizelos on 25 August 1920, o.s.).

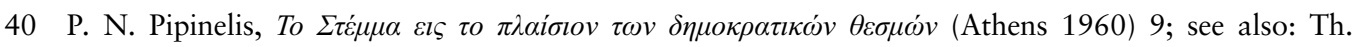

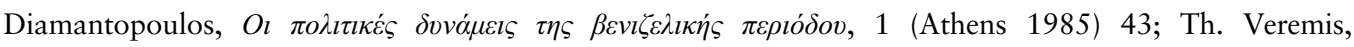

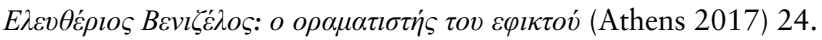

41 The Reservists (officially, the Panhellenic Association of Reservists) were a royalist paramilitary organization formed in the summer of 1916 in the immediate aftermath of the demobilization of the Greek army, following the demands of a collective note submitted by the Entente Powers to the Greek government on $8 / 21$ June. In the controversy between Venizelos and Constantine, the royalist agenda benefited from propaganda disseminated in the barracks and from the popularity that King Constantine had gained from his remarkable feats as Field Marshal in the Balkan Wars of 1912-13. See G. Th.

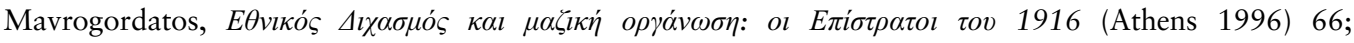

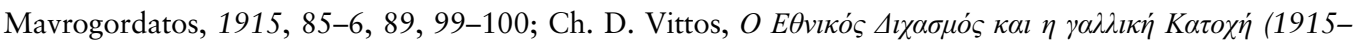
1920) (Thessaloniki 2008) 94-5; S. G. Ploumidis, 'From the Old to the New Greater Greece: The bellicose evolution of the Greek Great Idea in 1912-1913', Études balkaniques 49.2 (2013) 85-8. 
have most effectively rallied a wider following and sympathy for the Crown. Monarchy was systematically projected by staunch royalists, such as the Finance Minister Athanasios Eftaxias (1849-1931), as 'the pillar of order and peace' that averts 'civil conflict' and other socio-political dangers. ${ }^{42}$

In this crucial role, the monarchs of Greece were presented as 'the animated symbols of national unity'. ${ }^{43}$ The dichotomy between monarchy and anarchy was so deeply ingrained in the public imagery of the Crown and in civics education that not only accession to but also abdication from the Throne was interpreted as a sacrifice in the interests of averting anarchy. In the 1949 edition of the school manual on civics we read that in 1862 King Otto left Greece 'because he did not desire to cause a civil war' between his subjects. ${ }^{44}$ Likewise, the post-war historiographers of the monarchy cum civic educators remind us that sixty years later King Constantine, in an open letter to the prime minister (14 September 1922), presented his abdication as an act of 'patriotism' and 'royal gallantry' that aimed at forestalling civil strife and internecine carnage. ${ }^{45}$ In a similar manner, the abdication of Kaiser Wilhelm II in 1918 had been projected as a painful self-sacrifice for the sake of his people, so that the Reich might live in unity. ${ }^{46}$

Such discourse organically interwoven with the institution of monarchy was prominent in Greece during the First World War. From the onset of the National Schism, the royalists stigmatized Venizelos as 'a maniacal enemy of the King', ${ }^{47}$ and a herald of 'anarchy, national disintegration and internecine war'. ${ }^{48}$ They argued further that by disagreeing with the King and by abstaining from the national elections of 6/19

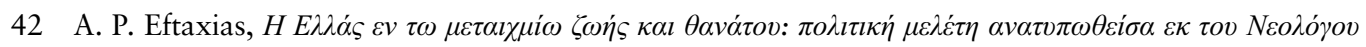

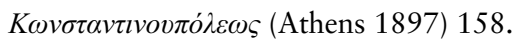

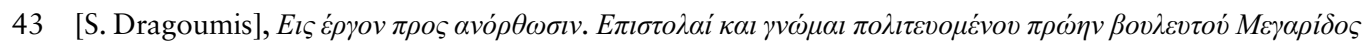

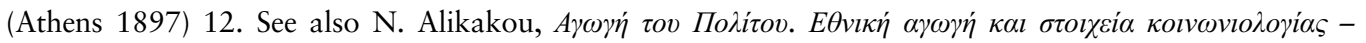

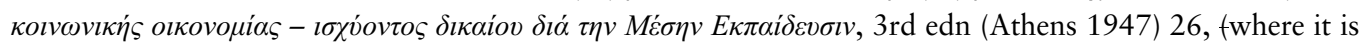
argued that the Crown and the royal insignia symbolize 'national unity'); cf. V. Bogdanor, The Monarchy and the Constitution (Oxford 1995) 63. In twentieth-century Greece, the German-inspired civic education (Staatsbürgerliche Erziehung) was the study of theoretical and practical aspects of citizenship. It included civil law and the basic concepts of government, as well as the rights and duties of citizens. Its principal aim was to instil the ideals of the rule of law, order and justice, and the principles of 'moral society'; see

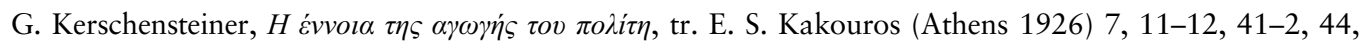
$53,68,70$.

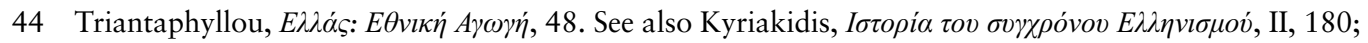
D. Dakin, The Unification of Greece 1770-1923 (London 1972) 88.

45 Triantaphyllou and Rozos, $O \Theta \varepsilon \sigma \mu o ́ \varsigma \tau \eta \varsigma ~ B \alpha \sigma i \lambda \varepsilon i \alpha \varsigma, 56-7$.

46 J. C. G. Röhl, 'The Unicorn in Winter: Kaiser Wilhelm II in exile in the Netherlands, 1918-1941', in P. Mansel and T. Riotte (eds.), Monarchy and Exile: the politics of legitimacy from Marie de Médicis to Wilhelm II (Basingstoke 2011) 337.

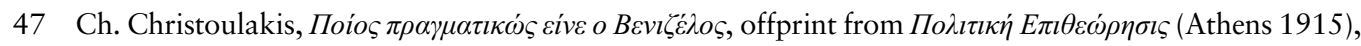

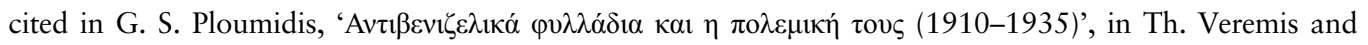

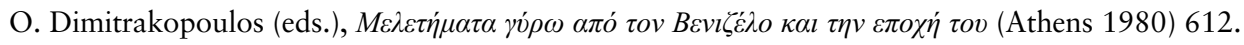

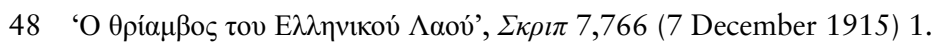


December 1915 Venizelos showed that he did not really want Greece 'to have a government or a king, so that the country remains in a permanent state of anarchy'. ${ }^{49}$ On this way of thinking, a vote for the anti-Venizelists meant the salvation of 'the Nation from anarchy'. ${ }^{50}$ For the anti-Venizelists the voters' choice was between monarchy and anarchy. ${ }^{51}$

In the same way, in the next general elections of 1/14 November 1920, which paved the way for the restoration of Constantine to the throne, Venizelos was once more identified with anarchy, trouble and abnormality: the ideology of Venizelism was castigated as 'an incitement to successive revolutions'; 'a source of troubles'; 'an unexpected whirlwind that blows from below and causes violent storms'; a danger to 'public order' and 'private interests', i.e. 'business and capital'. ${ }^{52}$ In the mind of steadfast royalists such as General Ioannis Metaxas there was no doubt that Venizelos was synonymous with 'social and state anarchy'. ${ }^{53}$ Therefore, in the narrative of the royalist press, a 'republican Greece' was an 'anarchic Greece' ${ }^{54}$, meaning a non-law-abiding polity marred by anarchy and internal turbulence. ${ }^{55}$

These arguments in defence of the monarchy were not short-lived weapons against Venizelos and his liberal radicalism. On the contrary, in the long term they proved to be quite solid and persuasive, as they consolidated the campaign for the restoration of Constantine in 1920 and George II in 1935 and 1946. Besides the revolutionary character of Venizelism, another key to their success was the threat of communism, which made its formidable appearance in October 1917 and added further conviction to the notion of anarchy. ${ }^{56}$ Within this new political framework, in 1920 a tenacious monarchy was presented by its adherents as 'a necessary bulwark and dam' against the 'flood' of communism and hailed as 'an instrument of order' against this new 'world class of revolutionaries'. ${ }^{57}$ In its envisioned new role, the monarchy was again contrasted with the republic, which was deemed incapable of counteracting the Bolsheviks of Lenin and Trotsky and stemming the Bolshevik current; in the event of

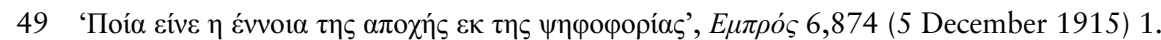

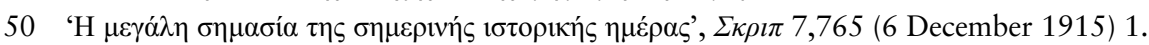

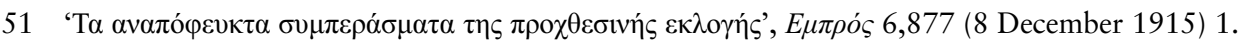

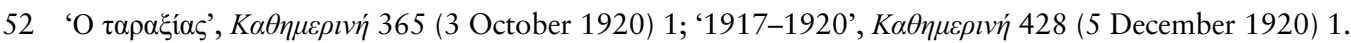

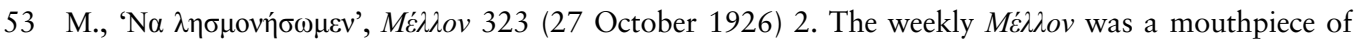
Metaxas' Free Thinkers' Party (est. 1922). It was published in Argostoli, Cephalonia, Metaxas' birthplace and powerbase.

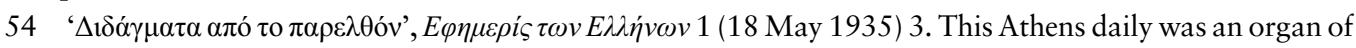
the Royalists' Union, a coalition of royalist parties that was forged under the leadership of Metaxas ahead of the general elections of 9 June 1935.

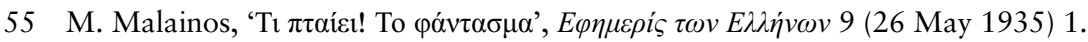

56 The Socialist Workers' Party of Greece joined the Third International in April 1920; see G. D. Katsoulis,

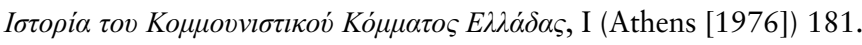

57 ' $\Delta \eta \mu о к \rho \alpha \tau i \alpha ; ', K \alpha \theta \eta \mu \varepsilon \rho \imath v \dot{~} 171$ (7 March 1920) 1. 
the parliamentary elections of 1/14 November 1920, Venizelos (as opposed to the exiled King Constantine) was accordingly identified as the Kerensky of Greece. ${ }^{58}$

In an analogous manner, in 1935, the return of George II to the throne was supposed, in his followers' eyes, to put an end to 'a long and turbulent period of political anarchy' and to terminate 'the twenty years of civil strife' which had started in 1915; on that account, the restitution of constitutional monarchy would restore 'order, peace and tranquillity, safety and stability' in the turbulent country. ${ }^{59}$ Restoration was propagated as the only 'way out of political anarchy', and a safeguard for 'political stability' and 'internal peace and order'. ${ }^{60}$ In addition to being identified with the calamities of the National Schism, republicanism was, in the referendum of 3 November 1935, also craftily associated with communism. The ballot papers in favour of the monarchy were printed in azure (the royal colour of the restored Bourbons in 1814-30), those for the republic in red. ${ }^{61}$

The initial enthusiasm over the restoration of George II receded rather quickly, for nine months after his return to the throne the king gave his consent to the suspension of the constitution and the establishment of an authoritarian regime under Metaxas. The King's popularity and image suffered terribly from his identification with Metaxas and his repressive measures. ${ }^{62}$ As a result of this, during the Axis occupation of Greece, while the king and his exiled royal government were in London, all the major resistance organizations (EAM/ELAS, EDES, EKKA and AAA) were avowedly republican. ${ }^{63}$

However, about a year after the end of the Second World War monarchy in Greece experienced another U-turn in its history. By 1946, the bitter experience of the dramatic internecine events of December 1944 (a Communist-led revolt in Athens) had obliterated the bleak memories of the royal coup of 4 August 1936 and the Metaxas dictatorship

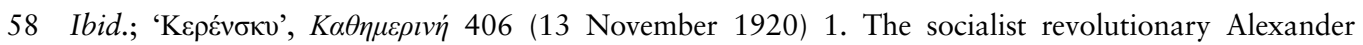
Kerensky was the head of the Provisional Government that was overthrown by the Bolsheviks on 25 October 1917 (o.s.). Henceforth, Kerensky's name became a synonym for political feebleness; see S. A. Smith, The Russian Revolution. A very short introduction (Oxford 2002) 34-9.

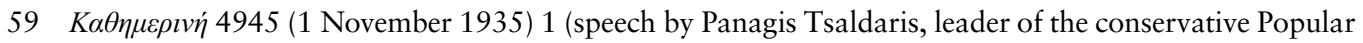
Party, to the 'People' of Athens); Г.A.B. [G. A. Vlachos], ' $\Sigma \tau \alpha \theta \mu$ ó $\varsigma^{\prime}, K \alpha \theta \eta \mu \varepsilon \rho v v \dot{\eta} 4948$ (4 November 1935) 1;

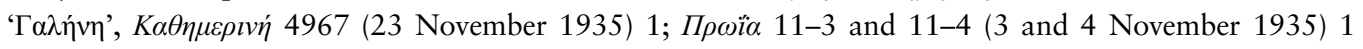
(addresses by Tsaldaris and Regent Georgios Kondylis 'to the Greek People').

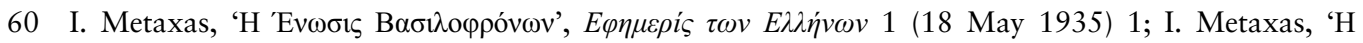

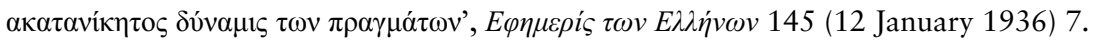

61 J. S. Koliopoulos, Greece and the British Connection 1935-1941 (Oxford 1977) 18-19, 25; G. Hering,

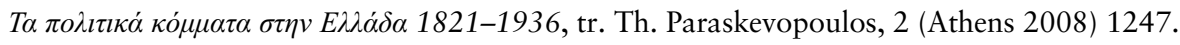

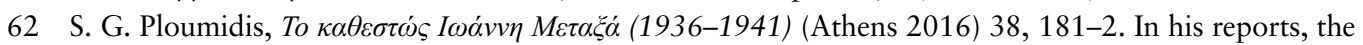
American Ambassador to Athens. Lincoln MacVeagh, identifies George II and Metaxas as 'Siamese twins', and their close relationship as the 'Gordian knot'; see J. O. Iatrides (ed.), Ambassador MacVeagh Reports. Greece, 1933-1947 (Princeton 1980) 150.

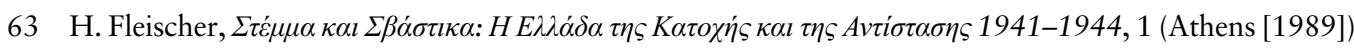
147-50, 371-2, 383, 387-8. 
(1936-41). ${ }^{64}$ In 1956, the academic historian Apostolos Daskalakis asserted that this traumatic experience had resulted once again in 'the people wanting above anything else the return of the king [George II] as a guarantor of order' and a deterrent against the 'anarchy' of communism. ${ }^{65}$ For - as the dominant political discourse had it - since 'the bands of anarchists' were preparing 'a revolution against government', and these 'anarcho-communists' were striving to lead the country into 'an internecine fight', the return of George II to his throne and the restoration of constitutional monarchy were portrayed as the only solution to Greece's political woes. ${ }^{66}$ Truly, the result of the referendum of 1 September 1946, which was overwhelmingly supportive of the monarchy, was more a vote of aversion toward the KKE than an expression of support for George's restoration. ${ }^{67}$ The Greek Civil War (1946-9) was another prime opportunity for the loyal supporters of monarchy to argue more emphatically that this form of government was 'the most suitable contemporary force that is indispensable both for peoples' welfare and for averting internecine wars and the turning of entire civilizations into ruins' ${ }^{68}$

After a relatively peaceful interval in the 1950s, the monarchy faced new challenges in the 1960s. The anti-communist trump card (along with the concomitant values of tranquillity, order, and social hierarchy) continued to be played by the Crown, but it did not appeal much to the 1960s generation, which was more attracted by the prospect of material progress and social equality. ${ }^{69}$ In a further setback, by falling out with strong political figures, King Paul, who had succeeded George II in 1947, and Queen Frederika were targeted by the entire political spectrum (Left, Centre and Right). ${ }^{70}$ In 1963, King Paul undermined and finally annulled a major constitutional

64 Technically, the Fourth of August regime was a royal dictatorship, akin to those of King Alexander in Yugoslavia, King Boris III in Bulgaria, and King Carol II in Romania. Kingship remained throughout its duration the cornerstone of its power structure; hence its most despised opponents were the Venizelists and Communists (venizelokommounistes), i.e. the arch-enemies of monarchy that had already been tainted as

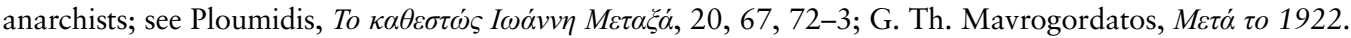

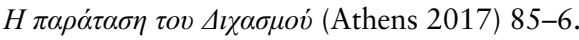

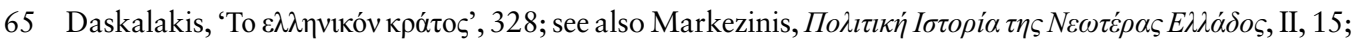

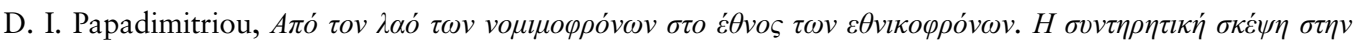

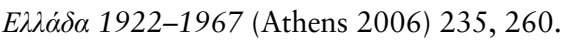

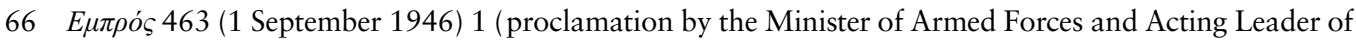
the Popular Party, Petros K. Mavromichalis, 'to the Greek people').

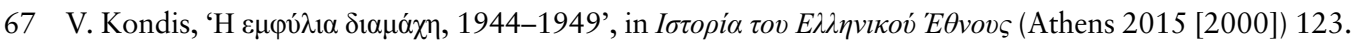

68 Triantaphyllou and Rozos, $O \Theta \varepsilon \sigma \mu o ́ \varsigma ~ \tau \eta \varsigma ~ B \alpha \sigma l \lambda \varepsilon i \alpha \varsigma, 5$.

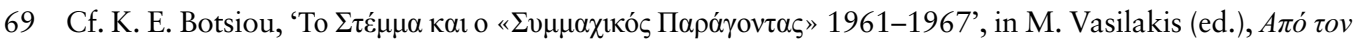

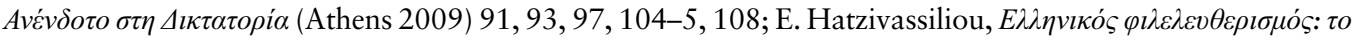

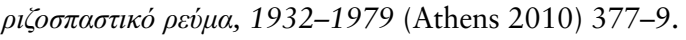

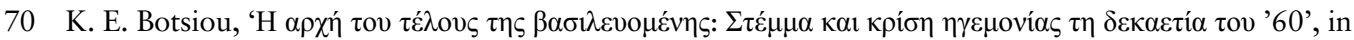

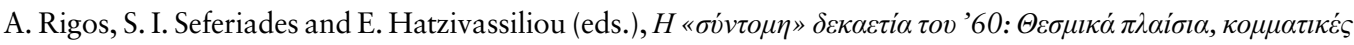

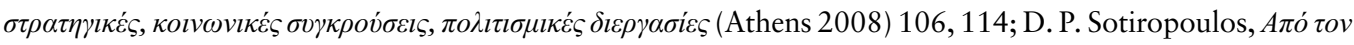

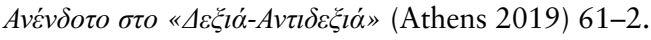


reform, historically known as the 'Deep Cut', planned by Konstantinos Karamanlis' centre-right government, which would have restricted the rights and prerogatives of the Crown. ${ }^{71}$ The breach between the king and the political elites culminated two years later in the resignation of Georgios Papandreou's centrist government and ended in political havoc. ${ }^{72}$

In the turmoil of the years 1965-7, Papandreou, a former Education Minister in Venizelos' government, recycled the memory of the National Schism of 1915-17 and, in imitation of Venizelos, launched a fierce anti-monarchist campaign. ${ }^{73}$ In reaction to this chaos, King Constantine II, who had succeeded his father Paul in 1964, fell back on his last stronghold, the army. However, the unanticipated coup of 21 April 1967 and the failed royal counter-coup of 13 December 1967 proved that the king had lost control of the armed forces, and he was forced into exile. ${ }^{74}$ The disgraceful entanglement of the throne with putschists and the egalitarian political culture of the 1960s eventually led to the abolition of the monarchy seven years later by a referendum after the fall of the military junta. ${ }^{75}$

Forty years after the abolition of constitutional monarchy, the discourse of the 'antidote to anarchy' still survives in Greece. Along identical lines with their predecessors, leading present-day champions of the Greek monarchy argue that this is the sole form of government that, 'in the best interests of society', can be the correct 'remedy' for or at least a 'sedative' to 'the excessive Ego and individualism of the Greek'; and the antidote for the 'chronic problem' of 'pitiless civil war', which constitutes 'a pathology of Greek political life since 1821'. As they see it, by being in a position to subdue the 'demon' of 'chaos', the Crown secures 'social cohesion' and offers a 'priceless service to the nation'.

\section{Epilogue}

This analysis concurs with Jeroen Duindam's argument that the monarchy is a multifaceted, complex and under-researched historical theme. The case study of

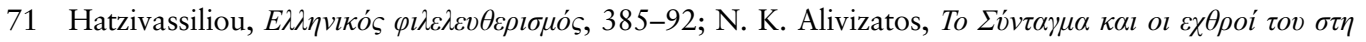

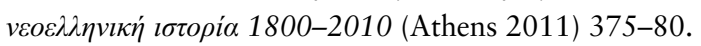

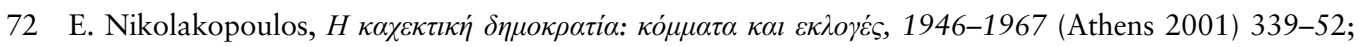

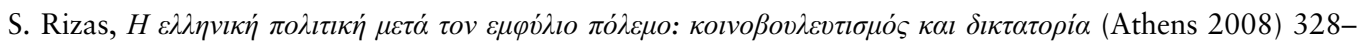

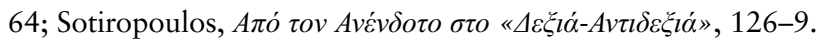

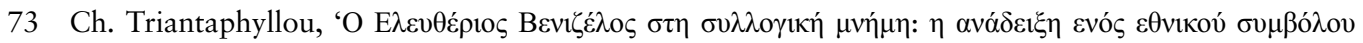

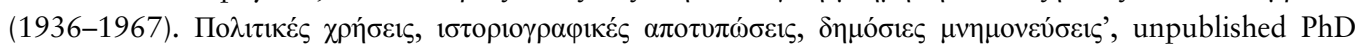
thesis, National and Kapodistrian University of Athens, Athens 2020, 191-2, 213-7.

74 L. Klarevas, 'Were the Eagle and the Phoenix birds of a feather? The United States and the Greek coup of

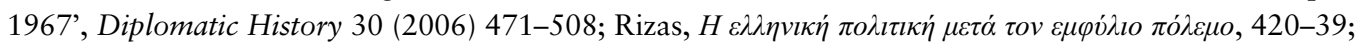

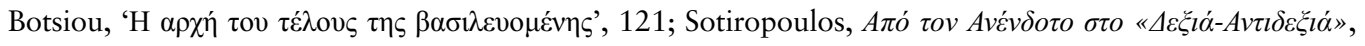
133-8.

75 The referendum on the form of government, which was held on 8 December 1974, returned a clear

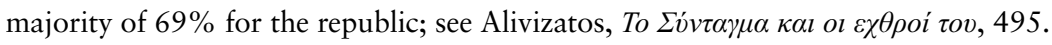

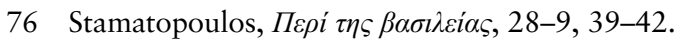


modern Greece corroborates that during the last quarter of the nineteenth century, despite all the upheavals and adversities, monarchy in Europe experienced a distinct upturn in popularity. In fact, the years 1880-1914 have been plausibly identified by historians as the last apogee of monarchy in Europe. ${ }^{77}$ Monarchy remained popular among Europeans primarily because it was the form of government most comprehensible to innately conservative peasants whose family lives were regulated by patriarchal principles. Moreover, while the political sway and influence once exercised by royalty abated, support for the Crown as the symbol of national unity, stability and permanence in a world of rapid urban and industrial change appeared to increase steeply shortly before the First World War. ${ }^{78}$ In addition to this, the multiple 'invented traditions' of royalty, such as coronations, pageantry, marriages, state visits and funerals, and the royal 'symbolics of power' (coats of arms, insignia, monuments, etc.) continued till the outbreak of the Great War to provide enormously popular spectacles for an increasingly literate mass audience. ${ }^{79}$

Ironically, the First World War constituted a 'revolutionary war' that dramatically altered the balance of political and social power in favour of liberalism, republicanism, ethnic nationalism, Bolshevism and feminism. It certainly emerges as a milestone in the history of monarchy in Europe, not least in Greece, where King Constantine was ousted in 1922 and a republic proclaimed two years later. ${ }^{80}$ The negative outcome of the Great War for the Powers of Central and Eastern Europe was regarded, to a certain degree, as a failure of monarchy. This is because, prior to 1914, royalty east of the Elbe had retained fundamental prerogatives in the conduct of military and foreign policies and symbolized the bellicose qualities of their respective nations. ${ }^{81}$

For this reason, defeat and the calamity of war, together with the incapacity of Europe's most autocratic and powerful monarchs to forestall armed violence, signalled the inglorious end of monarchy in Austria-Hungary, Germany, Russia, and Turkey. ${ }^{82}$ In Greece, the House of Glücksburg, on the basis of its royal prerogatives, was likewise held responsible for the catastrophic defeat of Greece at the hands of Kemalist Turkey in $1922,{ }^{83}$ with the concomitant loss of Greek-held Western Asia Minor and Eastern Thrace, ${ }^{84}$ and was formally ousted two years later, while the monarchy was simultaneously abolished. ${ }^{85}$

77 Spellman, Monarchies, 226.

78 Ibid., 210, 232-3.

79 Ibid., 233.

80 Friedrich, 'Monarchy', 414; Passmore, 'Politics', 93; D. Bacharas, 'La Grèce après la guerre: dictature et république dans un monde en mutation (1922-1925)', unpublished $\mathrm{PhD}$ thesis, École des Hautes Études en Sciences Sociales/Centre de Recherches Historiques, Paris 2010, 36, 330, 356-7.

81 Spellman, Monarchies, 235-6, 238.

82 Ibid., 242, 270; I. Kershaw, To Hell and Back: Europe, 1914-1949 (London 2016) 88-91.

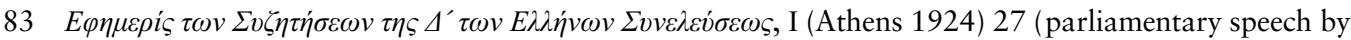
A. Papanastasiou, 23 January 1924, o.s.).

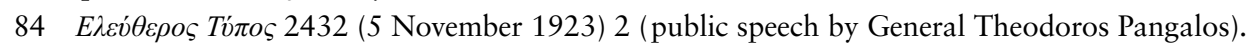

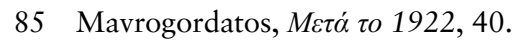




\section{Spyridon G. Ploumidis}

Yet, for all these vicissitudes, monarchy in Greece managed to survive its setbacks and to turn the tables twice in the twentieth century within a difficult domestic and international political environment. This success of the monarchy before the 1960s cannot be attributed solely to staunch royalism and the Machiavellian methods of the Anti-Venizelists, ${ }^{86}$ but to a great extent also to the powerful imagery and symbolism of the Crown, especially its definition as an antithesis of and its effectiveness against any form of 'anarchy' (civil war, banditry, left-liberalism, communism, etc.). Greece's low political culture ${ }^{87}$ and its long history of civil dissension greatly account for this appeal of the monarchical form of government. By virtue of its positive images and perceived extraordinary qualities as a rallying point, namely for being a rallying point of national unity and a powerful symbol of order and stability, royalty swayed the minds of Greeks.

Spyridon G. Ploumidis is Associate Professor of Modern Greek History at the National and Kapodistrian University of Athens. He read History at the Ionian University (Corfu) and holds a doctorate from the University of London. He has published numerous works on nationalism and ethnic rivalry in the Balkans (particularly in Greece and Bulgaria); agrarianism; corporatism; the Metaxas regime (1936-1941); the Asia Minor Question (1891-1922); and the Greek Revolution of 1821.

86 I am particularly referring here to the the referendum of 1935 , which returned a result of $98 \%$ for King

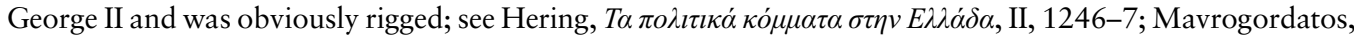

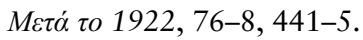

87 In Finer's terms, Greece falls into the category of countries of low political culture, in which localism and provincialism play a major role in politics, and pluralism is minimal: S. E. Finer, The Man on Horseback: The Role of the Military in Politics, 2nd edn (New Brunswick 2002) 129-31, 137. 